\title{
Waterpower romance: the cultural myth of dying watermills in German hydro-narratives around 1900
}

\author{
Agnes Limmer $^{1}$ (D) . Christian Zumbrägel ${ }^{2}$ (D)
}

Received: 4 December 2019 / Accepted: 7 July 2020 / Published online: 23 July 2020

(c) The Author(s) 2020

\begin{abstract}
Even in the twenty-first century, myths of preindustrial forms of energy utilization are woven around watermills, waterwheels, and traditional millscapes. Along German watercourses, many grinding shops and hammer mills held on to waterwheels and delivered mechanical rather than electric power well into the twentieth century. It is not the case that the days of these "old technologies" (Edgerton 2008) were numbered as soon as hydroelectricity and "modern" hydraulic turbines appeared in the $1880 \mathrm{~s}$. When analyzing the dominating contemporaneous discourses around hydropower, it is easy to overlook these tendencies of historical persistence. This is not surprising, considering that scientific, literary, and preservationist narratives around 1900 - actively and subtly-propagated and spread the idea of Muehlensterben, or the myth of dying watermills that has been rehearsed over and over again in reflections on hydropower history. In this article, we challenge the popular imaginaries of "old" and "outmoded" watermills in a two-step approach. Firstly, we contrast the well-known transition at the advent of hydroelectricity with hydropower activities, which took place simultaneously in Germany's traditional commercial landscapes. Here, waterwheels remained in good use, despite the electrification and scientific development of hydraulic turbines. Secondly, we deconstruct the romantic bias towards the preindustrial symbolism of the waterwheel by analyzing different arguments in professional journals as well as romanticizing and nostalgic literature. We combine approaches and empirical material of both historical and literary sciences to gain a better understanding of how different narratives reinforced the image of watermills and waterwheels being outdated. In this respect, the interdisciplinary approach contributes to the emerging field of the Environmental Humanities.
\end{abstract}

Keywords Hydropower - Waterwheel · Hydroelectricity · Heimatschutz · Muehlensterben · Preservationists · Romanticizing · Energy transition · Energy humanities · Environmental humanities $\cdot$ History of technology $\cdot$ Literary science $\cdot$ Environmental history

Agnes Limmer

a.j.flimmer@gmail.com; a.limmer@tum.de

Extended author information available on the last page of the article 


\section{Introduction}

In 1909, turbine engineer Rudolf Camerer published a handout for owners of hydropower plants entitled Was muss der Besitzer einer Wasserkraft vom Turbinenbau wissen? or in translation: What does the owner of hydropower need to know about turbine design? The chief engineer of the German turbine company Briegleb, Hansen \& Co., attempted both a historically conscious and a future-oriented diagnosis of contemporary hydropower developments:

Only 15 to 20 years ago, an expert could often be doubtful whether a turbine or a waterwheel was the preferable choice, given the contemporaneous state of turbine engineering. Today this situation has changed, as well-constructed turbines [...] combine so many advantages that the common waterwheel can no longer compete with them. Not long from now, it will be completely forgotten, suffering the same fate as the stagecoach, which could [...] nowhere obstruct the successful advance of the railroad. (Camerer 1909, p. 6) ${ }^{1}$

Camerer's phrasing is particularly drastic, but in general, he was not alone with his perspective. Around 1900, comparable estimates of technological change ran like a thread through publications in scientific engineering. Future orientated engineers contrasted the unbeholfene (heavy-handed) and unvollkommene (incomplete) waterwheel with the epochenmachende (epoch-making) hydraulic turbine. It was common understanding the latter was to displace the old technology from creeks and rivers within the nineteenth century (Camerer 1909, pp. 3-7). This hype about "modern" turbine technology derived from the latest achievements in electrical and hydraulic engineering. The electrification of hydropower--also known as "white coal" - called for high-level capacities and speed in hydraulic engines. Even though the practical use of hydropower had led to improvements in watermill and waterwheel construction for centuries, the new hydro-engineers, including Camerer, either neglected these previous achievements entirely or marginalized the waterwheel as an unvollkommene Vorstufe (incomplete prototype) of the modern turbine (Mattern 1908, p. 2, 267). Nevertheless, "old" waterwheels still outnumbered "modern" turbines in many places around 1900 - and far into the twentieth century. In 1927, for instance, three times more waterwheels than turbines rotated along the banks of Bavarian rivers and streams, mainly in low capacity plants (Zumbrägel 2018, p. 17).

This article investigates the long-term continuity of traditional hydropower technologies and sheds light on the disappearance of watermills and waterwheels as sources of energy in early twentieth-century discourses-at a time when those hydraulic engines were still widespread. We challenge the popular imaginaries of outdated technologies in a two-step approach. In the first part of the article, we introduce an almost forgotten piece of hydropower history to the well-known narrative around 1900, which concentrates on the transition that turned mountains and rivers into hydroelectric landscapes. Our examples refer to the technological persistence and co-existence of traditional mills and waterwheels that

\footnotetext{
1 "Noch vor 15 bis 20 Jahren konnte bei dem damaligen Stand des Turbinenbaues der Fachmann öfters darüber im Zweifel sein, ob eine Turbine oder ein Wasserrad den Vorzug verdiene. Heute ist dies wesentlich anders geworden, denn die Turbinen [...] vereinigen bei entsprechender Konstruktion so viele Vorzüge in sich, daß das Wasserrad schlechterdings nicht mehr in Wettbewerb treten kann. Die Zeit ist nicht mehr fern, wo es gänzlich vergessen und ihm ein gleiches Schicksal bereitet sein wird, wie der Postkutsche, die [...] das siegreiche Vordringen der Eisenbahn nirgends verhindern konnte."
} 
seldomly disappeared from one moment to the next. The second part of the article builds on these insights. Three contemporary narratives illustrate the radical shifts that hydropower underwent during the energy transition induced by industrialization and electrification.

We analyze different strands of literature and discourses, focusing on German debates in future-oriented engineering and contrasting artistic, cultural sources. While contributions in professional journals dismissed watermills and waterwheels as obsolete and historical, the latter idealized the watermill as a symbol of a preindustrial-and therefore outdated-idyll. These narratives had formative effects on hydropower historiography as well as the common notion of technological change in this field of energy right up to the present. Discourses around 1900 - actively or subtly-propagated and spread the myth of dying watermills or Muehlensterben as it is called in German. Still today, the watermill carries a distinct nostalgic imaginary on its romantic wooden waterwheel that is shrouded in the arcane idea of an exclusively preindustrial means of energy utilization. It seems that the awareness about the importance of traditional mills and waterwheels disappeared even faster than the utilization of these technologies.

This article seeks to embed the idea of Muehlensterben in its cultural context, questioning how it originated and coined present perceptions. To achieve this, we combine approaches and empirical material from the historical and literary sciences (Bergthaller et al. 2014). Integrating these areas of research enlarges our understanding of how the dualism of old and new hydropower technologies, which is an outcome of past debates, still dominates the public perception of this energy source. In this respect, the article contributes to the growing field of the Environmental Humanities, or, more specifically, to the Energy Humanities that historian Christopher Jones declared a new and important paradigm for cultural studies and the humanities (Jones 2016).

\section{Dam crazy for white coal}

At the turn of the twentieth century, a long-standing trend in the development of hydropower technology changed substantially. For centuries, humans had tapped the energy of flowing waters in small, scattered workshops for the benefit of private enterprises. Lots of waterwheels harvested the mechanical energy needed by sawmills, papermills, grinding shops, and corn mills. Utilizing energy of flowing waters for milling purposes shaped the character of preindustrial cultural landscapes. At that time, improvements in watermill and -wheel construction came from the traditional craftsmanship and know-how that ordinary technicians, mechanics, and mill operators had acquired through daily experience in their individual environmental settings (Langdon 2004; Lucas 2004). During the second half of the nineteenth century, the introduction of two new energy technologies led the exploitation of hydropower into new dimensions. The development of hydraulic turbines opened up every drop of flowing water to potential exploitation, and the new electricity enabled the transportation of hydropower over long distances from remote watercourses to centers of consumption. With the advent of turbine-driven hydroelectricity, new professionals entered the scene. Based on their techno-scientific expertise, hydro-engineers of a "new scientific era," replaced most local millwrights (Layton 1979, p. 65). They introduced hydraulic turbines, and soon their jargon began to dominate the scientific discourse on hydraulic engineering.

The rise of techno-scientific experts was one condition for the beginnings of the hydroelectric era. Within a few decades, hydropower facilities operated on a grand scale, and 
harnessing white coal became the preferred means of energy production. In Europe and North America, these requirements induced an explosion-like upswing of turbine development, construction, and sales at the end of the nineteenth century (Voegtle 1927, p. 49). From this point onward, traditional small watermills, powered by waterwheels, existed side by side with the new turbine-driven large-scale production units.

Hydroelectric power successfully captured the imagination of most Europeans. In the early decades of the twentieth century, hundreds of turbines, hydroelectric power plants, and dams both reflected and fueled anxieties as well as promises of this new technology. When engineers developed the first German dams in the late 1890s, the public became concerned about safety. These worries, were without doubt fuelled by spectacular dam collapses in Britain and France (Blackbourn 2006, p. 232). Other major projects, such as the run-of-river plant in Laufenberg, were fiercely attacked by representatives of the German Heimatschutz (heritage preservation) movement. Yet, most contemporaries enthusiastically hyped this new source of hydroelectric power. White coal promised clean energy in unlimited quantity and economic growth for the rapidly expanding industrial sector accordingly. The paradigm of rational and efficient (energetic) use of rivers was by no means new. It became simply exploited on an entirely different scale by means of hydroelectricity.

In search of white coal, engineers literally moved mountains and transformed rivers into "organic machines" as historian Richard White phrases it (White 1995). Massive hydroelectric run-of-river plants emerged on the shores of European and North American waters, profoundly altering riverscapes with their dams, diversions, and storage reservoirs. In the early years of hydroelectricity, Germans were mesmerized by the giant hydroelectric plant in Niagara Falls that commenced operations in 1895 (Binder 1999; Hunter 1980). In Germany, a power network proliferated in the rolling valleys of western Germany and

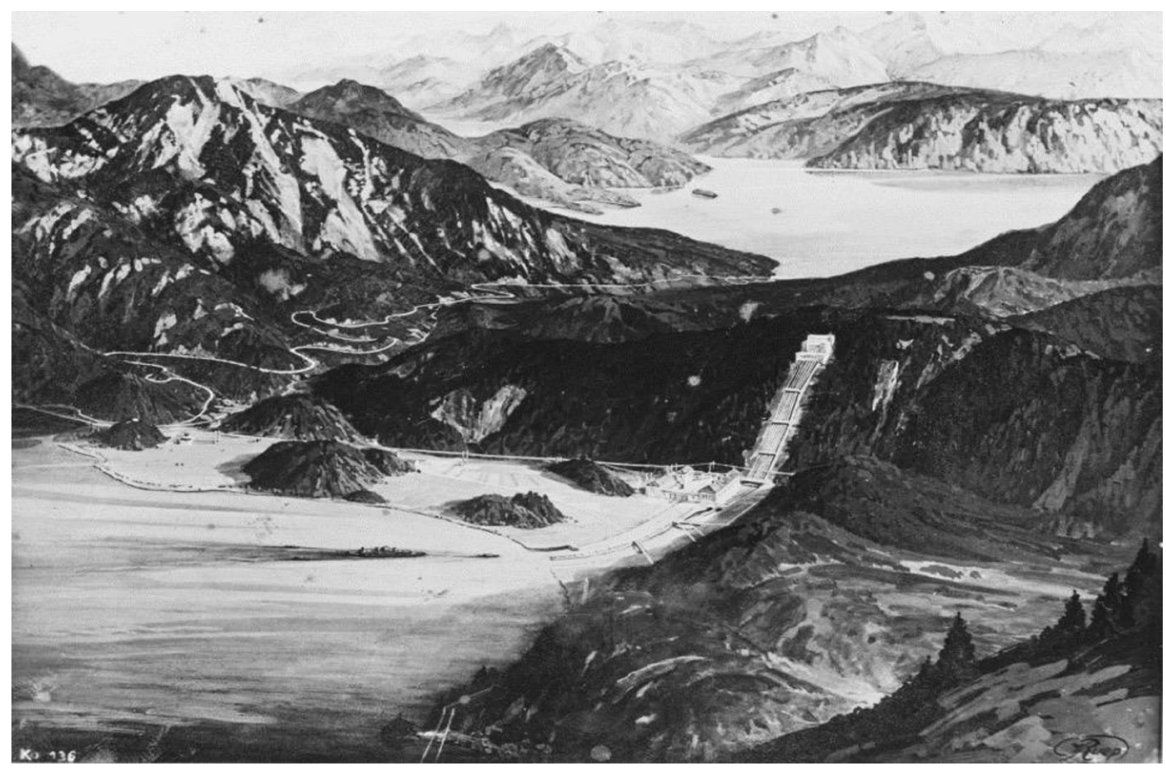

Fig. 1 The Walchensee plant in Upper Bavaria, one of the most iconic major construction projects of the Bavarian energy landscape. The idea to utilize the lake as a high-pressure power reservoir first emerged in the summer of 1904 and was realized in 1924 under the supervision of Oskar von Miller, a Bavarian hydroengineer (Deutsches Museum Archive) 
the coal-poor south. At the High Rhine and in the Alps, large-scale plants and reservoirs were constructed, substituting hydro for coal and expanding hydropower's role in electricity supply. Similar large-scale facilities arose in the USA, Canada, and European Wasserkraftstaaten (hydro-states) such as Switzerland, Italy, or Scandinavia (Gugerli 1996; Teisch 2001; Parrinello 2018; Cohn et al. 2020; Jakobsson 2002; Zimmer 2019). In Upper Bavaria, for example, the power potential between the lakes Kochelsee and Walchensee (Fig. 1) promoted a national myth of endless and environmentally benign electricity (Hughes 1983, pp. 334-350).

\section{De-constructing the hydro-narrative}

Stories of technological decline are a familiar narrative in the history of technology (Hård and Jamison 2005). As historian Heike Weber points out, recent historical accounts often pay tribute to decaying and deserted buildings, what could be summarized as a narrative of "ruin porn" (Weber 2019, p. 134). Although the conditions and consequences of technological decline and decomposition are seldom at the center of interest and easily overlooked. Those narratives are also common in the historiography of hydropower.

A representative example is the encyclopedia entry on Bavarian hydropower history in the Hist. Lexikon Bayern published in 2014, which states that waterwheels were replaced entirely by turbines at the beginning of the twentieth century. The author claims, turbinedriven power plants produced electricity and therefore made small mechanical working mills driven by waterwheels obsolete (Popp 2014). For a long time, historians explained shifts from one technology to another by those stage-by-stage transitions. Traditional waterwheels "could not meet the power requirements of the heavy industry after 1850 [...], it could only be met by the steam engine," George Basalla concluded in his Evolution of Technology (1988, p. 150). An older example is Terry S. Reynolds' history of hydropower Stronger than a Hundred Men (1983), that situates the "decline of the vertical waterwheel" in the nineteenth century, as it could not meet the demand of industrialization.

More recent studies from the field of history of technology describe such technological shifts as gradual processes that included various detours and lasted for decades in which old and new hydraulic engines coexisted or were hybridized (Parrinello 2018). Nevertheless, hydropower histories mainly highlight shifts from old and inefficient waterwheels to new, rationally designed turbines; from diffusion to a concentration of the power system; or from small- to large-scale facilities. However, reading hydropower history only through the lens of this alleged energy transition fails to capture the whole picture. It overlooks the stable factors in times of transition, like the persistence of mechanical working watermills and waterwheels.

Following the seminal work of David Edgerton's The Shock of the Old (2008), we assume that by focusing on the large-scale hydroelectric activities around 1900, contemporaries and historians failed to trace the existence of so-called "old technologies". Several historians point out that there is considerable evidence about contemporaries noticing changes in hydropower exploitation as a kind of energy transition (Blackbourn 2013). Historians deepened our understanding of the rise of scientific turbine research (Layton 1992; Malone 2009), the emergence of large-scale hydro-engineering projects (Lagendijk 2016; Cohn et al. 2020), and the environmental legacies of exploiting white coal (Landry 2015). Tracing the development in a long-term perspective by analyzing the large-scale view of demand counted in millions of kilowatt-hours displayed by national statistics, it becomes 
clear that the share of white coal in total energy production from hydropower continued to increase in the early decades of the twentieth century. This is one reason why historians have paid attention to the hydroelectric transition and broad economic shifts in energy utilization. However, deviations from the prevailing trends were frequently observed, given that hydropower use heavily depends on the natural conditions - in particular topography, rainfall distribution, and hydrological conditions - on a regional and local level. Recent studies in the Energy Humanities focus on specific regions at specific times (Zumbrägel 2020). They raised awareness of the geographic and temporal characteristics of energy-related processes to contribute to a re-reading of classical accounts of energy history. These had categorized the entire history of humanity into a small number of distinct stages of energy use and neglected geographical dynamics or diverse forms of energy production and use throughout history (Sieferle 2001 [1982]). This article is an argument for a more nuanced and creative use of time and scale in the history of this field of energy.

Local statistics, maps, and reports, therefore, often indicate characteristic developments that differentiate from the overarching trends in the energy sector. This is especially true for small creeks and streams in the southern Alpine regions as well as in Germany's Mittelgebirge (low mountain ranges). Due to their extensive water resources, the Eifel, the Harz, the Erzgebirge, and the uplands of Rhineland and Westphalia became early centers of economic and industrial activities. In these traditional commercial landscapes, local creeks had provided the basis for a thriving, small mill-based industry. Here, energy use remained anchored to old technologies long after the hydroelectric transition had begun and much longer than Camerer and his colleagues had predicted.

The Walchensee plant (Fig. 1) had been connected to the grid in 1924. Two years later, three times more waterwheels than turbines were rotating at Bavarian rivers and streams (Bayer. Statistisches Landesamt 1927, p. 36), which is indicated by the numerous small dots on a map published by the building authorities (Fig. 2). In the Bavarian Alps, engineer Fritz Kammerer counted 170 hydroelectric plants and "about 4000 mills, 600 sawmills, 900 saw and watermills, 1250 breweries, malting plants as well as chemical, metal, paper, and textile industry, quarries, potteries, and brickworks" ${ }^{2}$ that were all water-driven (Kammerer 1926, p. 104). Many of these plants continued to use mechanical energy into--and in some cases even beyond - the interwar period. Moreover, the waterwheel was indeed compatible with electricity production. Some mills' produced mechanical power in the daytime and electricity for lighting in the evening; or delivered the energy to the local grid. In rural areas, dispersed, isolated power plants where a mill operator produced electricity for himself and his local community accommodated the sources of hydroelectricity (Becker 1929; Reindl 1923). Those decentralized power systems were not exclusively powered by turbines, but also by waterwheels (Fischer 1930).

The capacity of these small workshops seldom exceeded 50 horsepower (HP) (approx. 37 kilowatts) (Fig. 3), which means large-scale modern plants provided most of the energy. Given their large number, however, the small-scale plants still contributed about 30 percent of Bavaria's total hydropower production (Hiltner 1931, p. 16). Therefore, Kammerer

\footnotetext{
2 "Es sind etwa 4000 Mühlen, 600 Sägen, 900 Mühlen und Sägen, 1150 Brauereien, Mälzereien sowie der chemischen, Metall- und Papier-, Stein-, Töpferei-, Textil- und Ziegelei-Industrie, dagegen nur etwa 170 Elektrizitätswerke. Die Kleinwasserkräfte kommen also hauptsächlich für Gewerbe und Kleinindustrie in Frage. Das entspricht auch der geschichtlichen Entwicklung dieser Betriebe, die sich entlang der Wasserläufe angesiedelt haben."
} 


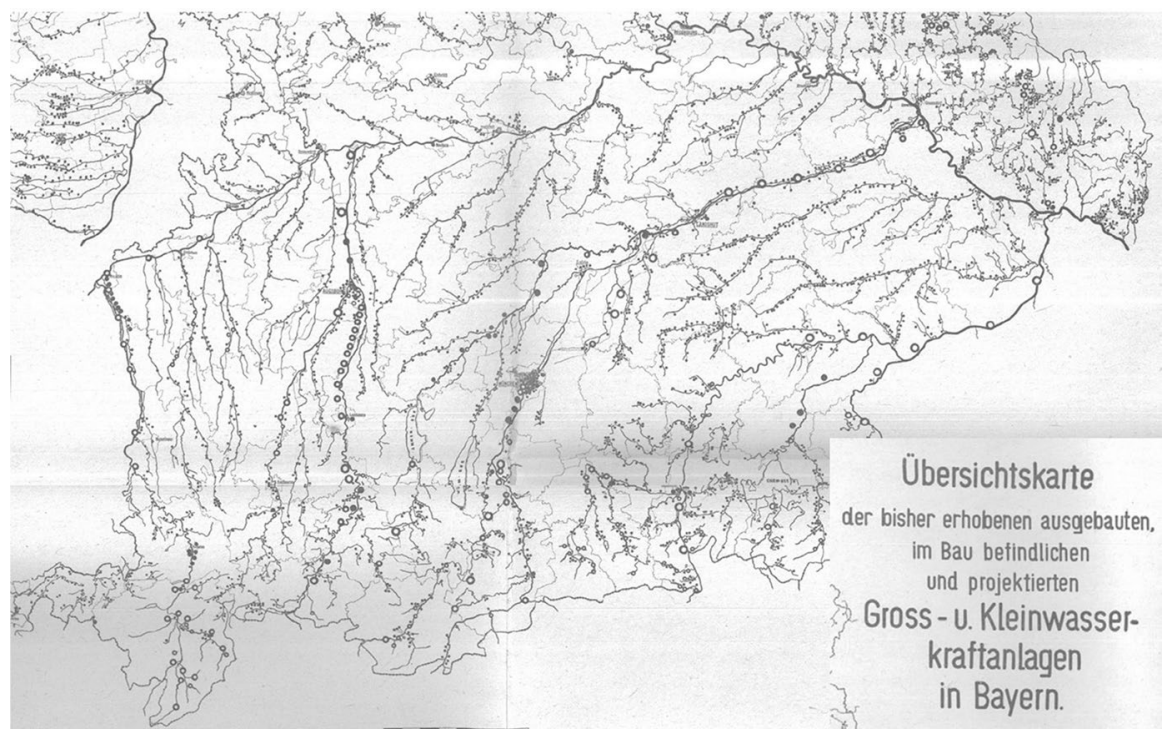

Fig. 2 The small dots signify water-driven workshops and factories that were clustered along the fast-flowing alpine streams, contrasting the younger turbine-driven hydroelectric plants indicated by the larger dots (Oberste Baubehörde 1921)

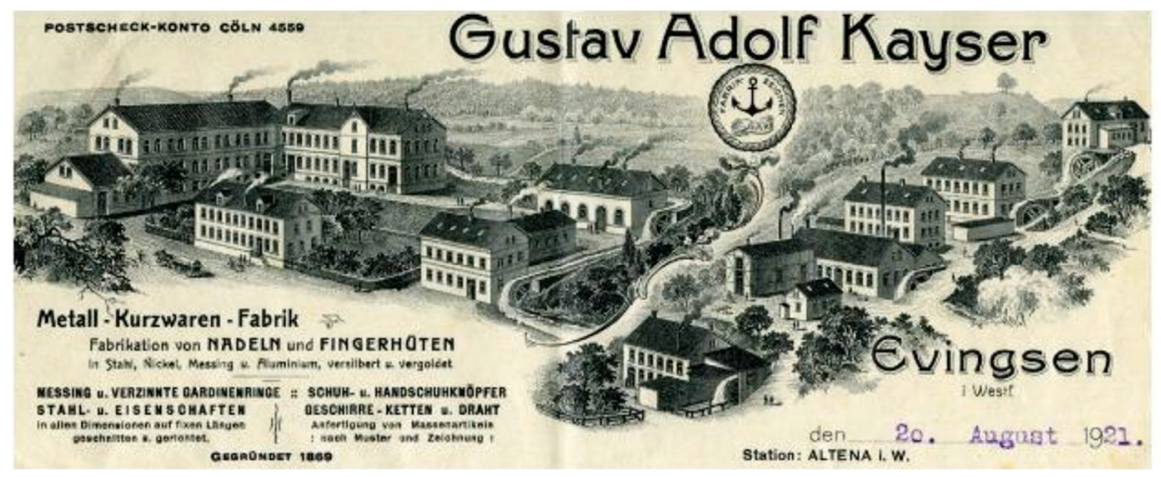

Fig. 3 Gustav Adolf Kayser powered seven wire and grinding mills with overshoot waterwheels (on the right) generating both mechanical and electrical energy still during the interwar period (Kreisarchiv Märkischer Kreis: BS 0251)

concluded, they remained vitally important for Bavaria's economy until the 1920s (1926, p. 105).

A similar picture emerges from the commercial landscapes of Germany's low mountain ranges, where einfache Wassermühlen (simple watermills) accounted for a significant part of local businesses long before the hydroelectric era began (Zoepfl 1902, p. 141). At the turn of the twentieth century, the Sauerland and the Bergisches Land in western Germany contained the highest density of waterwheels in the German Empire (Krümmel 1903, p. 172). And up through the 1930s, small wire mills, forges, and grinding mills equipped with waterwheels continued to outnumber turbine-driven 


\begin{tabular}{|c|c|c|c|c|}
\hline \multirow{2}{*}{$\begin{array}{c}\text { Werlgrößze } \\
\text { PS }\end{array}$} & \multicolumn{2}{|c|}{ 2̧afferrab } & \multicolumn{2}{|c|}{ Turbine } \\
\hline & $\begin{array}{l}\text { Baflic ber } \\
\text { Qmlagen }\end{array}$ & $\begin{array}{c}\text { भHobualeiftung } \\
\text { PS }\end{array}$ & $\begin{array}{l}\text { Bahl ber } \\
\text { Mulagen }\end{array}$ & $\begin{array}{l}\text { QusbauYeiftumg } \\
\text { PS }\end{array}$ \\
\hline $\begin{array}{rrr}1 & \text { bis } & 10 \\
11 & " & 20 \\
21 & " & 50 \\
51 & \prime & 100 \\
101 & \Rightarrow & 499\end{array}$ & $\begin{array}{r}6222 \\
877 \\
393 \\
62 \\
17\end{array}$ & $\begin{array}{rl}27 & 195 \\
13 & 120 \\
12 & 475 \\
4 & 501 \\
2 & 367\end{array}$ & $\begin{array}{r}1717 \\
818 \\
795 \\
297 \\
262\end{array}$ & $\begin{array}{rl}9 & 134 \\
12528 \\
26 & 645 \\
21 & 300 \\
55 & 575\end{array}$ \\
\hline
\end{tabular}

Fig. 4 This statistic displays that waterwheels continued to power small workshops located at minor rivers and creeks: especially in low capacity metal-, paper- or glass-making mills, with a mechanical power-output of maximum 50 HP (Bayer. Statistisches Landesamt 1927, p. 36)

hydroelectric plants there (Fischer 1930, p. 36, 42). The continuity of small-scale industries was because traditional waterwheels remained better suited to the environmental and social conditions along the local watercourses, where mill owners did not always require massive amounts of energy. In many cases, reliability was more important. The old technologies usually proved cheaper to maintain and repair when problems inevitably arose, caused by sediments and flotsams, which could damage the sensitive turbine technology far more easily than traditional waterwheels. Last but not least, the old technologies responded better than turbines to fluctuating water levels, which were typical for the fast-flowing creeks (Zumbrägel 2018).

Despite techno-scientific engineers like Rudolf Camerer predicting the demise of the waterwheels, the uplands of Rhineland and Westphalia developed into a real hot spot for the persistence and proliferation of traditional hydropower facilities. This contributed significantly to the local energy supply until well into the interwar period. Some of the old waterwheels even received a new purpose in the electricity supply. Enterprises like the metal factory Gustav Adolf Kayser-introduced on the letterhead in Fig. 3-connected some of their waterwheels with a generator to provide electric light for a few hours in the evening. To fully understand the energy transition towards fossil fuels and hydroelectric facilities, Edgerton (2008) urges us not to look at the latest and most innovative technologies, but rather to examine the most common technologies that remained in wide use (Fig. 4).

Historians widely neglected that small water-driven workshops continued to produce energy long after the era of large-scale dam projects and the production of white coal had begun. Different factors account for this lack of interest. For example, the continuous use of a technology traditionally has been regarded as secondary to the initial choice, design, and evolution of a technology, and its analysis requires sources that are difficult to assemble (Lindqvist 1994). The resulting historiographical gap also relates to the fact that the continuous processes in hydropower history remain almost invisible when focusing on the historical analysis of dominant contemporary discourses on hydroelectric transition. Here, contemporaneous narratives labeled and idealized waterwheels and watermills as typical technologies of a bygone historical era and thereby reinforced images of them being outdated.

Analyzing different hydropower discourses around 1900, we aim to identify significant stories of decline at a time when the traditional, old technology was still in use. Hydro-engineers, for example, labeled waterwheels as primitive and inefficient to underline the innovative character of their newly designed turbine technology. Contrasting 
assessments surface in romantic narratives of early eco-novels as well as statements of the German Heimatschutz movement. Whether future-orientated or romanticizing, both strands of hydropower discourses have one thing in common. They were rehearsed over and over again in reflections on hydropower history in the twentieth century and therefore contributed to constructing the cultural myth of dying watermills.

\section{Imaging a turbine-driven future}

At a time dominated by techno-optimism, major parts of society were ready to follow the promises made by the proponents of the new hydroelectric era. Experts from academic institutes like the Technischen Hochschulen (polytechnical colleges) and large turbine companies were the leading proponents. Adopting David Blackbourn's terminology, we call them the "hydro-enthusiasts" (Blackbourn 2006, p. 219). This group consisted of experts or specialists-most notably college-educated engineers, but also leading politicians and business people, for example, managers of leading turbine companies. The enthusiasts made their case by pointing towards a hydroelectric future based upon high-performing hydraulic turbines, large-scale, centralized electricity production, and long-distance transmission to centers of consumption. In the eyes of most hydro-enthusiasts, harnessing rivers was the harbinger of modernity. Mesmerized by the idea of tapping into the Kapital der Berge (capital from the mountains), they were outspoken advocates of technological progress (Hennig 1909, p. 209). Not surprisingly, their strategy included replacing old hydropower facilities performing mechanical work by large-scale units producing vast amounts of electricity (Koehn 1909, p. 112).

During the first decade of the twentieth century, new professional journals appeared on the market with titles like Die Turbine (The Turbine), Die Weiße Kohle (White Coal), or Zeitschrift für das gesamte Turbinenwesen (Journal for Turbine Affairs). Academically trained enthusiasts pushed energetically for large-scale hydroelectric expansion in the pages of their rapidly multiplying engineering journals. They left no doubt that these efforts proved wildly successful. However, they also casually appreciated traditional hydropower facilities. Camerer, for example, stressed that infolge ihres Alters (because of their age), waterwheels belonged to the "most venerable prime-movers" (Camerer 1909, p. 4). Despite such statements, the majority of the hydro-enthusiasts explicitly distinguished their scientific turbine research from the experience-based methods of traditional craftsmanship.

Many of these journal contributions spread the assumption that exploiting hydropower by small grain and hammer mills was a wasteful use of a precious resource. Hydroelectric pioneer Emil Mattern worried about a vast number of traditional small and scattered facilities jeopardizing the fruits of his large-scale hydroelectric plans (Mattern 1908, p. 523, 628). Similarly, Oskar von Miller, Bavaria's most prominent forerunner of hydroelectricity, deplored what he considered as a regellose (disorderly) exploitation of small-scale hydropotential in a decentralized system, where the sources of power production were dispersed willkürlich (randomly) across the land (von Miller 1908, p. 401). His colleague Theodor Rehbock, hydraulician at the Technical University of Karlsruhe, complained about the Wasserkraftverschwendung (waste of hydropower) by small and outdated mills (Rehbock 1908 , p. 1). According to the common technological paradigm of a rationalized, centralized, and above all large-scale harnessing of white coal, engineers agreed that even a large quantity of traditional mills could never compete with one large-scale production unit of the hydroelectric era (Vogel 1905, p. 612). One central idea of this future-orientated 
scientific community stated that small and traditional was anything but rational. In addition, hydro-enthusiasts attempted to create an evolutionary view of technological change. They labeled small mechanical working mills equipped with waterwheels as old, primitive, and inefficient. In contrast, they admired hydroelectric projects driven by turbines as rationally designed masterpieces embodying the age of modern hydroelectricity and scientific research. This distinction manifested itself on different scales.

Until the eighteenth century, technical references in hydropower literature actually consisted of "a description of the arts, especially the mechanical" (Nye 2006, p. 12). For centuries, the term Kunst (art) had been the wording of choice in the technical literature on watermill construction (Sturm 1718; Behrens 1789). Experts regarded Kunst or rather Kunstfertigkeit (artistry) as a quality feature honoring the traditional craftsmanship involved in hands-on and practical millwrighting (Popplow 1998, p. 7). In their efforts to distinguish scientific-based knowledge from the millwright craft tradition, hydro-engineers ousted the term Kunst from the jargon of the prevailing academic discourse. In the early years of the twentieth century, Theodor Koehn and Ernst Reichel noted that modern theoretical and scientific skills were to be acquired at turbine testing rigs and no longer through hands-on activities and practical experiences at streams and rivers (Reichel 1914, p. 4; Koehn 1908, p. 477).

In later editions of his reference work on hydraulic engineering, Ludwig Quantz excluded the chapter describing the waterwheel, because he considered it obsolete, merely persisting anachronistically (Quantz 1907 [1929]). Measuring energy in kilowatts instead of horsepower, for example, seemed like a symbolic break with the old and outmoded. "There is something wrong when an engineer has to measure the prospects of a hydroinstallation based on what a horse costs," claimed engineer Ludwig Fischer-Reinau (1908, pp. 102-103). ${ }^{3}$ Engineer Camerer visualized the new relation between existing knowledge and technologies that had characterized hydraulic engineering for centuries even in the illustrations of his books (i.e. Camerer 1914, p. 227). In Fig. 5, he contrasted the technical sketches of a small and compact high-speed Pelton turbine (top right) and the enormously large waterwheel to point at the disproportional space and material requirements when constructing a waterwheel by in traditional style, but with modern capacity. ${ }^{4}$

Conceptions of technical progress pervaded a variety of engineering publications, but they also manifested themselves in the didactic mediation of technological development. For example, Conrad Matschoß - an engineer and prominent figure in the early German history of technology--was profoundly influenced by an affinity to evolutionary thinking. While visiting the exhibition of hydraulic engines at the Deutsches Museum in Munich in 1925, he noticed "the museum exhibits technical artifacts of old watermills next to models of modern hydroelectric projects, which helped the visitor appreciate the paramount significance of turbine technology" (Matschoß 1925, p. 127).

Comparing waterwheel and turbine, engineers attributed the alleged reasons for the decline of traditional hydro-equipment to its technological backwardness. Max Grantz, a professor of hydraulic engineering in Berlin, suggested a long-lasting stagnation in the development of artisan technologies (1907, p. 158). This was contrasted by the immer größeren Vervollkommnung (ever greater perfection) of hydraulic turbines that enabled

\footnotetext{
3 "Nebenher will ich [...] nur noch darauf aufmerksam machen, dass wir mit dem alten Begriff PS [...] brechen müssen. Es ist in ganz gleichem Masse etwas nicht in Ordnung, wenn ein Ingenieur die Ausbaufähigkeit einer Wasserkraft danach beurteilen will, was ein Pferd kostet."

4 Pelton turbines were primarily used for high heads and small amounts of water.
} 
Fig. 5 In publications, hydroenthusiasts distinguished their contemporary scientific turbine research from the backyard trialand-error methods of the preindustrial arts and crafts workshop. Camerer contrasted the huge, but slow waterwheel with a compact, speedy, and rationally designed hydraulic turbine (picture in the top right corner) (Camerer 1914, p. 227)

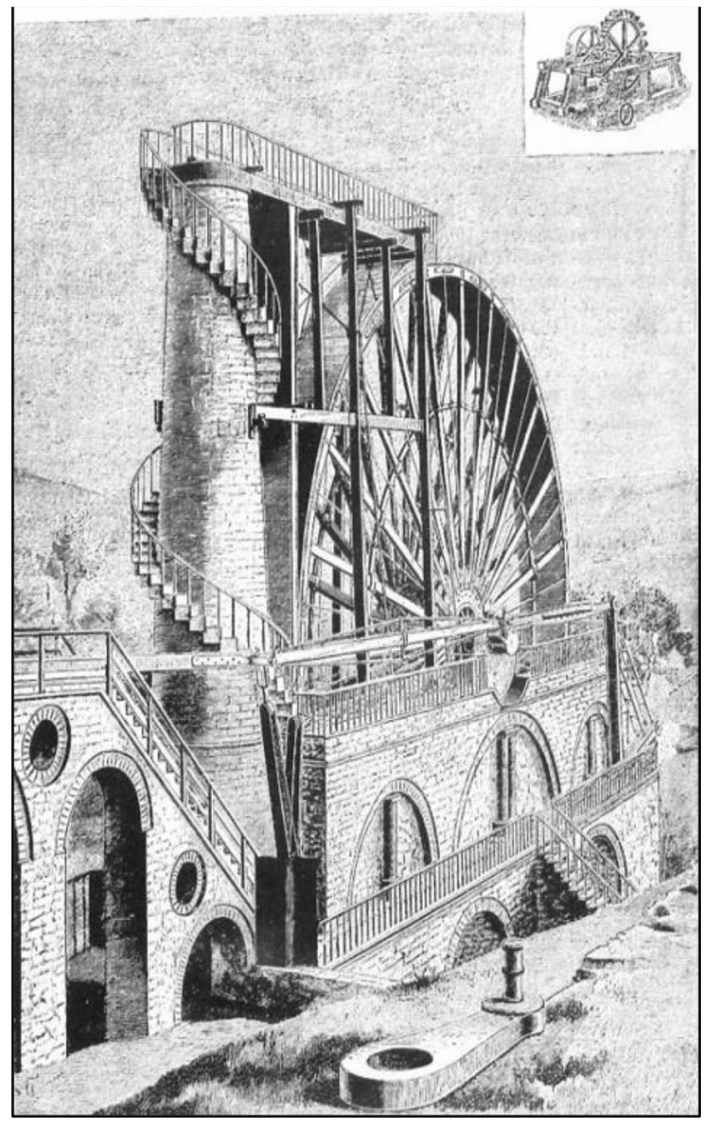

them to surpass waterwheels over the course of the nineteenth century (Meyer 1908, p. 264). Some technological parameters express these improvements in scientific turbine research. At the end of the nineteenth century, academic institutes and companies established turbine testing rigs, where hydro-engineers worked to develop rationally designed turbines by improving high-level capacities and speeds (Thoma 1928/1929). Thereby engineers achieved some remarkable successes. In less than fifty years, the widespread Francis turbines changed from far below $500 \mathrm{HP}$ in the 1860s to more than 100,000 HP at the turn to the twentieth century (Winkel 1927, p. 45). The efficiency of Francis turbines lay below 75 percent in the 1880 s, while later models exceeded 90 percent at the beginning of the new century (Voegtle 1927 , p. 10). ${ }^{5}$

Hydro-enthusiasts--as well as historians of later times--neglected, however, continuous improvements of the old waterwheels. In the commercial landscapes of Germany's low mountain ranges, ordinary technicians, mechanics, and millwrights made great efforts to adapt different waterwheel designs to local hydrological conditions (Müller 1899, p. 2). Even at academic institutes, a small number of engineers continued to devote themselves to constructing more efficient waterwheels. In the 1920s, professors Anton Staus and Karl

${ }^{5}$ Francis turbines were primarily used for medium heads and flows. 
Meerwarth of the hydraulic laboratory in Esslingen in the southwest of Germany, tried to transfer the handcraft technology to a scientific level (Staus 1928). They improved some practical features of these old technologies, like the durability and resistance, by reinventing the waterwheel using modern materials and design. With a few exceptions, however, the capacities and speeds of their "modern" waterwheels remained limited (usually below 100 HP) (Hoyer 1922, p. 351; Reindl 1923, p. 134). In the eyes of many hydro-enthusiasts, these differences were reason enough to propagate their high-performing turbines as the technology of the future.

Engineers used their enhanced visibility in techno-scientific journals to push forward their turbine research. Discursively, this became obvious when they emphasized a sharp distinction between the traditional handcraft of ordinary millwrights and the "turbinization" and "scientification" of hydropower business. Marginalizing and ignoring waterwheels in their publications, hydro-enthusiasts attempted to stress their technological achievements as superior and to give them scientific legitimacy. In this respect, engineers attached the label "old" and "new" in a targeted and conscious way. This discursive strategy also served a social function by assigning cultural significance to their scientific innovations in engineering science.

\section{Longing for a picturesque landscape}

At the turn of the twentieth century, nostalgic returns to the picturesque and romantic watermill with its wooden waterwheel were furthermore the result of criticism accompanying the transformation of rivers by large-scale hydroelectric plants. Influential representatives of the early German heritage preservation movement raised their voices by threatening to stop or sabotage radical landscape disfigurements. While preservationists opposed the plants and dams of the hydroelectric era, they contributed to shaping romantic images of old mills beside rushing streams by denouncing the destruction of tradition.

Such landscape disfigurements would be disappearing waterfalls, winding rivers, or picturesque valleys (Dominick 1991). Their imaginary, however, continued to exist as memories and illustrations in literature and the arts (see the section below). As the example of the Walchensee plant demonstrates, protest distinctly targeted the conservation of the aesthetic value and beauty of the local natural landscapes. Local heritage preservationists were not primarily concerned about the ecological destruction of the lake area. Their objections concentrated on the overall aesthetic importance of Bavaria's Alpine lakes. The lakes' unique turquoise color, they argued, would be ruined by sediment carried in the river Isar and the shores' appearance could suffer by the alterations of the water level caused by hydroelectricity (Landry 2013, p. 120). The ecological damage that natural protectionists criticized in the second half of the twentieth century, only found their way into the discourse when economic disadvantages affected the tourism in the Alps or local fishery (Hasenöhrl 2011, pp. 124-162; Schoder and Schmid 2017).

A well-known example from the early Heimatschutz is the conflict surrounding the hydroelectric plant at Laufenburg (Baden) during the first decade of the twentieth century (Cioc 2002, p. 132; Linse 1988). As soon as the construction of huge dams and long-distance transmission lines began, a consortium of large banks and companies of the electricity producing industry projected a power plant with an output of 50,000 HP, more than twice the size of comparable objects along other European streams (Zeller 2007, p. 25). The project came under attack from members of the Bund Heimatschutz, founded in 1904, 
whose petitions argued the dam would destroy a series of highly scenic rapids, "one of the most beautiful landscape scenes in Germany, or indeed the world" (Bund Heimatschutz 1904/1905, p. 69). ${ }^{6}$

The Bund Heimatschutz put tremendous effort into its attempts to stop the construction. For example, the organization initiated a nationwide public awareness campaign to raise concern about the loss of this picturesque landscape (Lekan 2004, p. 60). In the end, their protest remained unheard. A regional advisory board and the Baden government approved of the project in short order, arguing it could attract business and industry to the economically weak region. After the plant's finalization in 1914, the scenic rapids at the High Rhine disappeared without public notice. Nevertheless, the protest movement continued, and the Laufenburg campaign eventually pointed the way towards later opposition against largescale interventions in natural landscapes (Uekötter 2015, p. 45).

The construction of large-scale power units, dams, and artificial lakes were obvious and significant interferences with the landscape (Landry 2015). Disputes over hydropower plants were, therefore, among the "classical nature protection conflicts" with a long history (Engels 2006, p. 159). The preservationists' criticism focused on the transformation of natural spectacles, which they perceived as picturesque natural heritage that needed protection. Among them were the Laufenberg rapids, the Alpine panorama or the mountainous landscapes of Saxony, Rhineland and Westphalia that advanced to hotspots for the proliferation of dams and reservoirs. They also criticized the Verdrahtung (wiring) of idyllical valleys with Wäldern (forests) of grids (Löhner 1912; Klotzbach 1920). Public resentment grew particularly when local actors implemented hydro-projects without considering an area's scenic beauty. For example, such radical interventions affected the Oker valley in the Harz mountains in the middle of Germany (Fig. 6). Within a few years, the pristine valley turned into scree, because an increasing number of water-powered factories channeled the river Oker into pipelines (Fricke 1911). Some hydro-enthusiasts even criticized this degree of transformation. In 1908, the engineer Fischer-Reinau claimed a sin was committed against the kostbare Gabe der Naturschönheit (precious gift of natural beauty) in this valley (Fischer-Reinau 1908, p. 106).

The Bund Heimatschutz was one of several organizations dedicated to the preservation of traditional values and the criticism of industrial progress. However, the organization gathered members from a variety of societal and political backgrounds (Rohkrämer 1999, pp. 113-114; Schmoll 2004, p. 417). These included conservative anti-modernists like the Landschaftsanwalt (landscape advocate) Ernst Rudorff, a professor at the Berlin musical college, who was radical in his views. He considered hydroelectric projects of every type and size as a Verunglimpfung der Landschaft (disparagement of the landscape) caused by the Herrschsucht (imperiousness) of the industry (Rudorff 1904/1905, pp. 175-180). Other members, like the economist Carl Fuchs, who had initiated the protests around the Laufenburg plant, proved rather open-minded towards landscape transformations, as long as industrial progress did not threaten the Wunder der Natur (marvels of nature) (Fuchs 1905, p. 93; for Fuchs' position see also Rollins 1997, p. 142). Even the engineers and architects of the hydroelectric plants occasionally participated in public discussions about landscaping (Stürzenacker 1925/1926).

\footnotetext{
6 "Nach Zeitungsnachrichten steht die Genehmigung des derzeitigen Projektes eines Kraftübertragungswerkes bei Laufenburg, durch welches die dortigen Stromschnellen, eines der schönsten Landschaftsbilder Deutschlands, ja der ganzen Welt, vollständig zerstört werden sollen, unmittelbar bevor."
} 
Fig. 6 Heritage preservationists made the Oker valley a symbol of the negative effects of hydropower on the natural landscapes (Schultze-Naumburg 1916, p. 134)

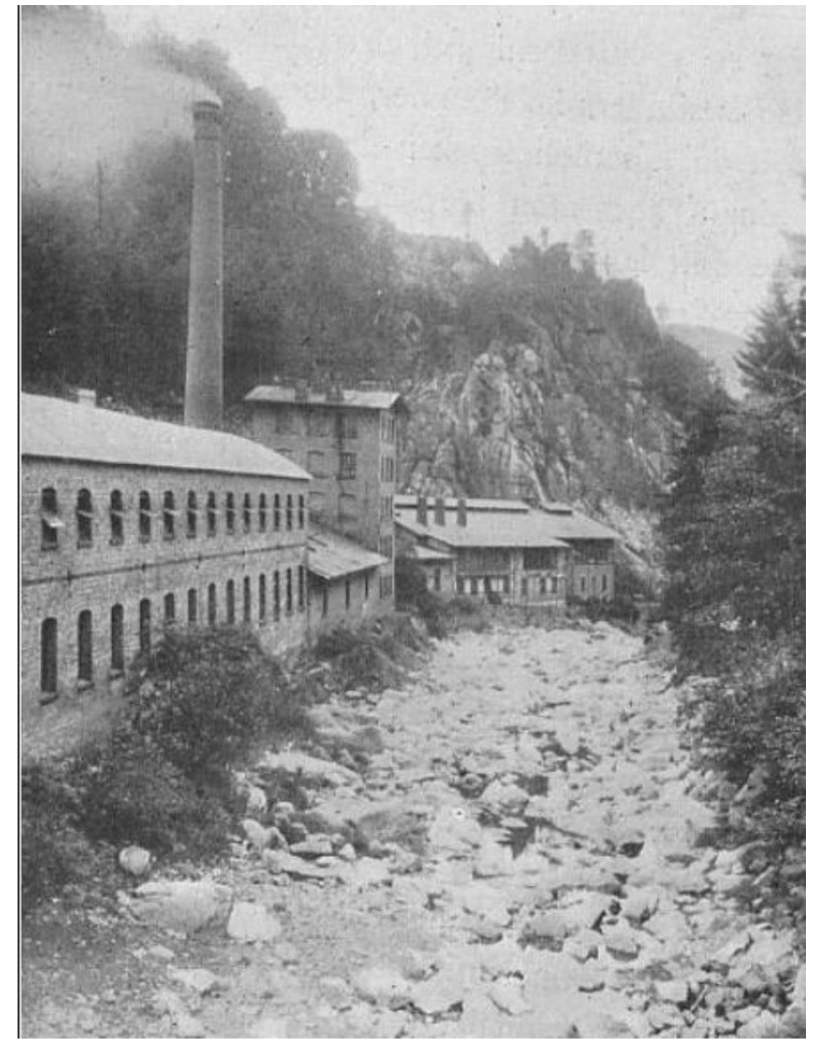

Apparently, the aesthetic arguments of the Heimatschutz supporters called at least for a response. Over time, noted Otto Löhner, later chairman of the Bund Heimatschutz, hydroenthusiasts increasingly showed goodwill to consider the preservationists' claim to implement new technologies with respect to aesthetical aspects of the natural landscape (Löhner 1912, p. 224). In the years around First World War, architects and engineers reflected about these concerns in the design of some large-scale hydroelectric plants, like the Murgwerk in the southern Black Forest (Koch 1924) and the Walchensee plant in Upper Bavaria already mentioned. Both were functional power plants that renounced adornments and ornaments, which acknowledged hydro-technology "in harmony with nature" (Rollier 1912, p. 184).

Compared to the radical destruction in the Oker valley, some heritage preservationists could even find some aesthetic beauty in the artificial lakes of modern dam constructions. As architect and chairman of the Bund Heimatschutz Paul Schultze-Naumburg suggested, these barrages could produce anmutige (charming) landscapes (1916, p. 146). Only in their size, the reservoirs would differ from the small millponds of the old hammer mills, which were an aesthetic Bereicherung (enrichment) of the rural scenery (1906, p. 133). As a consequence, he not only complained about the effects of the Oker valley transformation; he also worked out tangible suggestions for improvement. Schultze-Naumburg drew attention to the ästhetischen Werte (aesthetic values) of traditional watermills in its altehrwürdiger Gestalt (time-honored design) (1906, p. 130). In his view, nobody would ever regard these traditional worksites as "ugly" (1905, p. 69). 

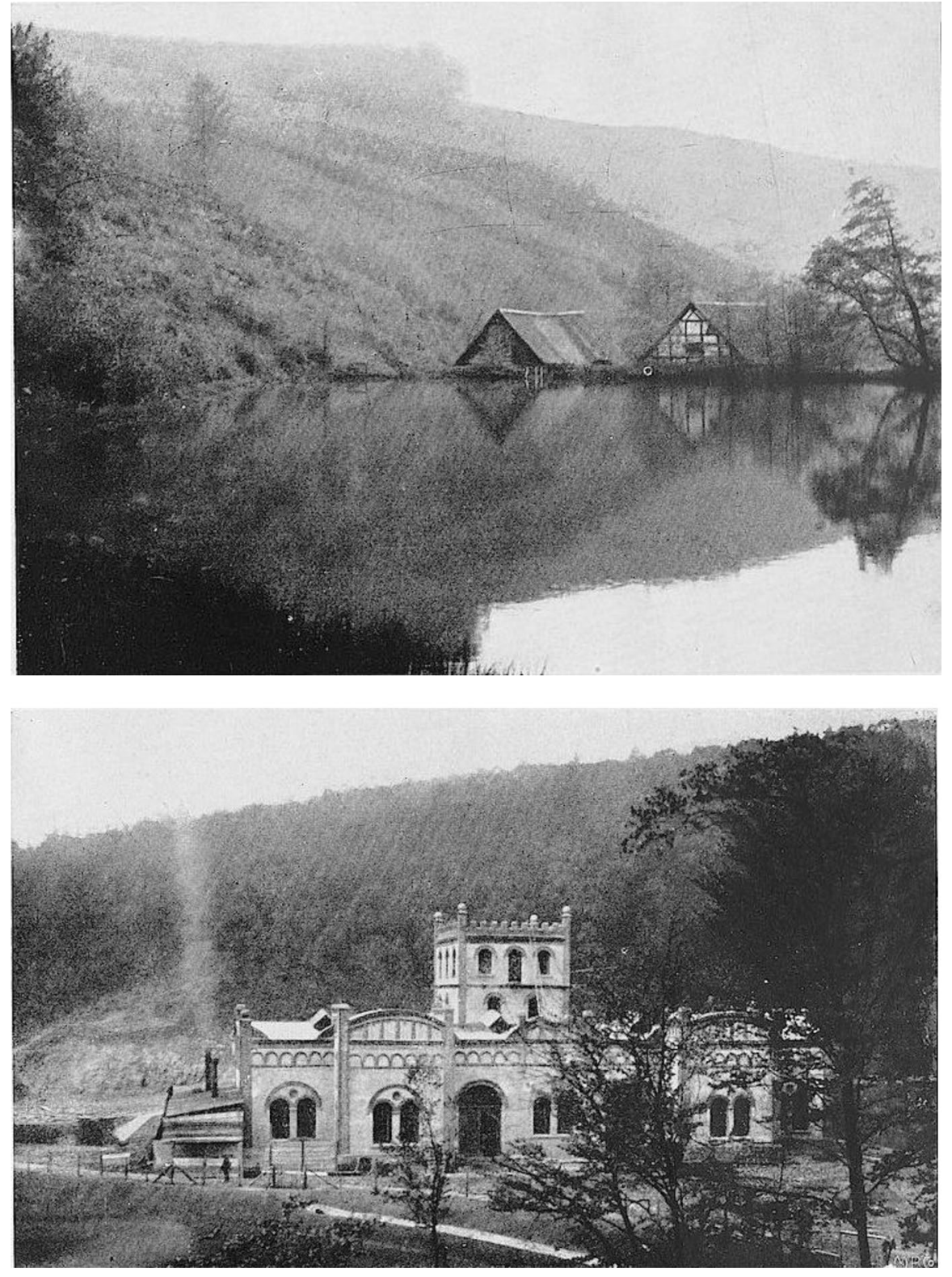

Fig. 7 Comparison of a scenic watermill with millpond (top), located in the mountainious terrain of the West German Sauerland, and an ornate hydroelectric power station (down) (Schultze-Naumburg 1905)

Comparing the photograph of a traditional watermill, he suggested that every viewer would agree the term beautiful was "rather befitting for this picture" (Fig. 7, top). He contrasted the mill with the photograph of a power station located in Germany's low mountain ranges (Fig. 7, down), attributing its extraordinary ugliness to the Gestaltungsunfähigkeit (design inability) of his era. Previous times would have understood better to design 
technical arrangements harmonisch und schön (harmonious and beautiful), instead of such jämmerlich albernen Aufputz (pitifully silly finery), the architect concluded (SchultzeNaumburg 1905, p. 72).

Preservationists advocated for aesthetics of simplicity and clarity, embodied by watermills and waterwheels in their typisch-schlichten Bauweise (typical simple construction) (Lindner 1926, p. 13). They embedded their thoughts about the compatibility of technology and landscape in a neo-romantic narrative. This narrative contrasted the negative effects of the industrial age with the beauty of traditional millscapes from a bygone technological era (Schultze-Naumburg 1906, p. 73; see also: Schoenichen 1929). The Heimatschutz discourse turned the old watermill into a unifying symbol of a past economic system, in which societies and their technologies were in harmony with nature. Here, traditional millscapes were part of a primeval and pristine nature; they did not dominate the landscape, but arranged themselves with it and harmoniously embedded themselves into it. The traditional milling culture became a safe harbor for concerns about the loss of scenic attractions that modern hydroelectricity threatened in their existence (Binder 1999, pp. 252-255).

On the one hand, this romantic image concealed the significant interventions into the hydrological cycle and conflicts with other water users that characterized the commercial activities along many watercourses since its early times. Mills and waterwheels were commercial businesses and in this function places of hard, physical labor-far from romantic natural idylls (Bayerl 1987, p. 51). On the other hand, the Heimatschutz discourses and writings bear witness to the "ruin porn" fascination for deserted places and aesthetics of decline (Weber 2019). Many of the watermills in the traditional commercial regions that Schultze-Naumburg and others fought over, remained widely in use. These written accounts portrayed discursively mediated sensations rather than an accurate description of the technological change along the watercourses. They stand as a nostalgic retrospective, which is also a recurring phenomenon in many historical accounts of the declining traditional millscapes. This is reflected both in book titles such as Vergehende Welten (Decaying Worlds) or Die letzten Hammerwerke (The Last Hammermills), outcomes of the local historiography in the Sauerland and Bergische Land (Claas 1929; Wildemann 1931).

While industrial operations based on local waters and traditional waterwheels still characterized these mountainious areas of West Germany, historian Wilhelm Sellmann described the local milling industry simultaneously as an example of an "old, long gone time". It was one of those dramatic and backward-looking obituaries on the early process of industrialization that occurred in the Ruhr area during the interwar period when Sellmann noted:

Modern times have no contemplative retrospect; everything is set for purpose, and most of the mills had to be sacrificed to this practical thought. The peaceful clacking of the mills in the valleys has been silenced [...]; today, the tremendous symphony of work is roaring; smoking chimneys stretch their gigantic forms into the air, where formerly the small mill used to nestle against the water. (Sellmann 1930, p. 346) ${ }^{7}$

\footnotetext{
7 "Die moderne Zeit kennt keinen beschaulichen Rückblick; alles ist auf Zweckmäßigkeit eingestellt, und die meisten Mühlen mußten diesem praktischen Gedanken geopfert werden. Das friedliche Klappern der Mühlen in den Tälern ist verstummt [...]; heute erbraust die gewaltige Symphonie der Arbeit; qualmende Schlote recken ihre gigantischen Formen in die Luft, wo früher die kleine Mühle sich ans Wasser schmiegte."
} 
The narrative of decline was firmly rooted in the thinking of many conservationists and preservationists. $^{8}$ They wrote recollections that focused on what had been, but not what was. While Rudorff, Schultze-Naumburg, and Sellmann were longing for picturesque millscapes, they contributed to shaping romantic images of old and outmoded technologies. Many of the attributions encompassing today's imaginations of the watermill as an exclusively preindustrial form of energy utilization are inherited from these early coined narratives of decline and idyll.

\section{Romantically fallen for the past}

By the time Camerer and his techno-modernist colleagues promoted their scientific-based technologies to the professional audiences, public opinion about modern development had already fallen for their visions. When a seemingly endless stream of articles imagining a hydroelectric future inundated the scientific community, it was accompanied by poetic and autochthonous literature and arts, accounting for the mutually stimulating interaction between science, arts, and everyday life. Almost concurrent with the industrial revolution's progressive narrative, a counter approach to modernization had gained momentum. Romanticism embraced the past, and with respect to technology, its simple but efficient and "down to earth"-mechanics. Poetics and emotions were employed to create a counter-world for humans to exist within a techno-modernity, where landscapes were highly symbolically charged (Preisendanz 1966; Nünning 2009). Natural spaces became more than landscapes, they became places of personal and psychological development and fulfilled specific narrative functions (Klimek 2012). They were also inscribed with a symbolic meaning to its ecological, geographical, and aesthetic transition that was induced by the construction of hydropower plants, dams, and their reconstruction of the German waterscapes. Such a reading of landscape change also encompasses the meaning of broader social processes and the systemic change that is represented by the death of the watermill.

During the long nineteenth century with its multi-faceted literature, historicism played an important role in shaping the romantic imaginaries of old and outmoded technologies. At the beginning of the century, it provided the setting for development novels such as Johann Wolfgang von Goethe's Wilhelm Meister (1795), where the stage was set for a nostalgic approach towards the past, and thereby for its technology. In the high romantic literature of Novalis Heinrich von Ofterdingen (1802), Joseph von Eichendorff's Aus dem Leben eines Taugenichts (The Life of a Good-For-Nothing) (1826) or ETA Hoffmann's Der Goldene Topf (The Golden Pot) (1814), the Middle Ages were even stylized as a "golden-past" as compared to liberation wars and political restoration. Remote historical spaces-featuring waterwheels and small watermills--subtly criticized this increasingly depressing present (Weglöhner 2006). Soon, this present was overshadowed by smokestacks in their panorama of industrial production sites. In the juxtaposition of literary Romanticism and Modernity, these watermills and their waterwheels became schemes of the past themselves. At the same time, the narrative landscapes of an idealized past were affected by the subconscious psychological transformation of the society that accompanied the technological transition. At the end of the long nineteenth century, historicism served as a tool to shape

${ }^{8}$ The preservation of monuments was a central field of work in the Bund Heimatschutz. 
the political and economic identity of the young nation-states that imagined themselves a techno-modernist future.

Hydro-enthusiasts consequently evaluated such "tales of the past" as a sign of romantic "backwardness" and anti-progressiveness, tied to the past but also to distinct natural localities, where the watermill became the central topos for a pre-industrial idyll (Bayerl 1987, p. 72). Covering a broad range of cultural fields, advocats of Romanticism as a general mindset understood it as a form of cultural protest surfacing in times of significant transformation (Löwy and Sayre 2002). We argue that localized and often rural stories of the romantics are not only loosely connected with local history writing and heritage preservation. Written texts propose alternative environments and, by the act of imagination, affect an individual's "caring for the physical world" (Buell 2001, p. 2). The texts featuring modernist landscapes without or with destroyed watermills shaped the set of cognitive associations of the public. They thus paved the way for the common acceptance of the cultural myth of the dying watermill.

Watermills appear in every genre of romantic literature and the fine arts, encompassing novels and short stories as well as paintings, librettos, or music pieces, such as Robert Schumann's Liederzyklus (Songcycle) (1840) and Robert Eilenberg's Mühle im Schwarzwald (Black Forest Mill) (1885). The popularity of these works serves as evidence for the shared understanding of the symbolism of traditional technology and its function in transforming landscapes. Supported by the gramophone, the hydropower discourse received an audio track that promoted romantic feelings towards the watermill even more widely. The gramophone as a modern technology also signifies the social change from participatory salon culture to modern cultural consumption. Commonly understood as promoting nostalgia, the waterwheel stood stigmatized as an adversary to progress. Over the decades, romantic themes and subjects became firmly entangled with the movement itself. In the case of the watermill, this thousands of years old technology turned iconic for a romantic bias towards the world and in addition, almost literally suffered the movement's fate. From the mid-nineteenth century onwards, Romanticism became gradually replaced by the new Realist and Naturalist movements that fully established the watermill as a symbol of the past and of societal change. Public opinion increasingly viewed it as outmoded and overhauled. It had died.

The artistic death of the watermill features most prominently in Wilhelm Raabe's novel Pfister's Mill published in 1883. Its story is set in the northern part of the Oker valley, where industrialized production of refined sugar (itself a source of agriculturally produced energy) with its intensive use of water resources paved the way for the later piping of the rivers into hydro-energy production. Raabe used the analogy of the dying watermill as a symbol of the Kaiserreich's (German Empire) transition from agrarian to industrial society. Still, the artistic style also shows a transition from literary Romanticism to Naturalism, which is characterized by its sober and science-inspired narration (Wanning 2005).

Even though Raabe proved highly critical of the progressive industrial development, he himself becomes a perpetrator of the cultural myth in question. Raabe employs pollution as a poetic practice that invades and colonizes the language of his realist fiction that is eventually overpowered by the environmental degradation it depicts (Wilke 2011, p. 198). The traditional mill dies at the hand of a modern industrial sugar plant, whose pollution chokes its tributary creeks. On a metaphorical level, the refined beet sugar "fueled" the industrialization by providing metabolically easily accessible caloric energy to the workers, who could, in turn, fuel industrial progress (Pritchard and Zeller 2010, pp. 82-84).

Gradually, the waterwheel in Raabe's story gets covered by biological organisms to a degree that inhibits its turning, threatens human health, and undermines the mill operator's 
economic existence. In the process of replacing waterwheels with turbines, environmental pollution features as a side-story that surely deserves to be told. Raabe explicitly mentioned "turbines" that were affected by fungi and algae, when he was preparing his manuscript (Limmer 2019, p. 105). Eventually, the old technology is replaced by the new. Modern progress cannot be detained, yet, Raabe hides his critical reflection under an intricate fabric of dark humor (Kneitz 2016). In Pfister's Mill, the landscape conversion subsumed under the "conquest of nature" seems discursively inevitable. This resonates well with contemporary newspaper reports that discuss the need to replace watermills due to their vulnerability in the wake of modern technological alternatives. ${ }^{9}$ Comparable to other regions in Germany, Raabe's place of agrarian nostalgia, the duchy of Braunschweig, maintained its dominant form of traditional energy production well into the twentieth century. Small subsistence businesses remained dependent on hydropower generated from shallow creeks with slow water flow (Berg 1995).

Besides their environmental and economic advantages (Rutschmann 2013), waterwheels seemed perfectly fit for the local geographical disposition. Already when Raabe wrote about Pfister's dying mill, the local watershed was affected by seasonal changes in the water level that were induced by the spikes in resource consumption of the local beet sugar refineries. By the early 1890s, however, when water quality had gotten under control, large-scale hydropower plants were constructed in the Harz region and lower Oker valley. We can assume that their operations considerably influenced Braunschweig's water balance. Raabe's vision of a shifting pollution paradigm, that also stands symbolic for a shifting energy paradigm, was not incorrect.

Proto-eco-critic Wilhelm Raabe critically observed the historic, romantic, and ecological sides of technological progress over his entire career (Limmer 2019). In his oeuvre, the dying or decaying watermill is a recurring theme and symbol. Staged in the Harz region, his short story "Die Innerste" (The Innermost) (1874) brings up the aesthetic, ecological, and social consequences of watercourse design. Along its course, smelting works polluted the river and human intervention ecologically threatened the river--that would also cause the death of the local watermill. The literary piece is designed as a fairy tale that can stylistically function to cognitively distance the reader from an urgent problem and thus provide a reflective space. The genre further provides a set of known narratives and associations for the reader to relate to:

There were three Fräulein about 120 years ago, and they are still alive today and are called the Leine, the Ihme and the Innerste. They have been regulated through the ages; but they have not become prettier by it. 120 years ago, all three of them could not be trusted; but the Innerste was the worst and has remained so until the present day. If the old saying is true that bad company corrupts good manners, it is true in this case. (Raabe 1874 , p. 1$)^{10}$

Again, this story is an example of the author's skepticism, here towards river regulation, even though it is depicted as the contemporary success story it accompanies. A story of

\footnotetext{
9 Raabe W Nachlass-H III 10. City Archive, Braunschweig.

10 "Es waren drei Fräulein vor etwa hundertundzwanzig Jahren, und sie leben heute noch und heißen die Leine, die Ihme und die Innerste. Sie sind im Laufe der Zeiten reguliert worden; aber hübscher sind sie nicht dadurch geworden. Vor hundertundzwanzig Jahren war ihnen allen dreien nicht zu trauen; doch die Innerste war die schlimmste und ist es bis auf den jetzt vorhandenen Tag geblieben. Wenn wo das alte Wort Gültigkeit hat, daß schlechter Umgang gute Sitten verdirbt, so ist es in diesem Falle."
} 
human violence overcomes a discrepancy between environmental history and the public narrative. It represents the domination of nature by taming the previously wild waters of a natural watershed (Wilke 2016). With its submission, also traditional forms of energy production become outmoded, but not due to a technological default, but due to changing environmental parameters. The techno-modernist hydro-enthusiast story of water turbine success has mostly left these out. A traditional watermill cannot operate with the increasing volume and speed of waters moving downstream, a morphologically altered river course. Therefore, river regulation as both prerequisite for and consequence of harnessing energy from running waters must be included in the myth of the dying watermill.

\section{Beyond decline and idyll: conclusion}

At the beginning of the twentieth century, the imagination and perception about what was to be considered as old and inefficient on the one hand and new, efficient on the other hand, quickly manifested itself among the public, science, and politics. In fact, the persistence of what was usually labeled old and outmoded, presents a recurring phenomenon in hydropower history. This applies to many traditional commercial regions, such as the Alps and the low mountain ranges of western Germany, where these old technologies remained crucial to the local industry until the interwar period-even though hydraulic turbines and hydroelectric facilities were widely available.

Both hydro-enthusiasts and preservationists perceived the industrialization and hydroelectrification as times of transition--but they assessed these changes differently. While some recognized them as processes of social and technological progress, for others, they were an expression of social decline and the destruction of traditions and scenic beauty. They argued from different points of view, but the impact was similar: while enthusiasts marginalized and preservationists romanticized the waterwheel, both strengthened dichotomizations between old and new hydropower technologies.

Millscapes and waterwheels are an interesting example of continuity at a time when gigantic hydroelectric dams began impounding main waterways. In this respect, the article is not an appeal for replacing the dominant large-scale approach with an exclusive focus on the persistence of old technologies in certain regions. Rather, the article has used another point of view to contrast the well-known hydroelectric transition with different hydropower activities and discourses to unravel the romantic bias towards the preindustrial symbolism of watermills and waterwheels. By engaging with empirical material of both historical and literary sciences, we can help to overcome simplistic representations in the development of hydropower technology.

The future-oriented academic hydropower discourses and romanticizing literature around 1900 contributed to spreading and constructing the myth of the dying watermill that determines the every-day perception of technological changes in hydropower history right up to the present. Current discussions feature historically minted dichotomies of old and new, simple and complex, or even good and bad technologies. Recent publications in hydro-engineering reproduce arguments of bygone days, branding waterwheels as outdated, primitive, and inefficient and identify newly designed Durchströmturbinen (cross-flow turbines) or Wasserkraftschnecken (hydrodynamic screws) as technologies of a sustainable future energy regime (Schnell 2015, p. 466; Gschwandtner 2013). Facing reductionist ideas of technological development affecting recent energy decisions, the history of technology plays an important role. Historcial insights from this field can complicate the concept of 
a neat energy transition by referring to the complexity of technological changes in past energy transitions. In this respect, two key insights can be gained from the analysis of the article:

In current hydropower discussions, not only technological and economic parameters-i.e., performance and profitability of engines and plants--are defining conditions for a future expansion of this energy source. The planning and realization of a hydroelectric project goes hand in hand with complex societal requirements and, above all, ecological concerns. Therefore, it is surprising that current energy discussions rarely consider traditional waterwheels that could find renewed popularity in the twenty-first century. Even today, the value of a small watermill driven by a waterwheel is not yet limited to a nostalgic decoration of restaurants and touristic trails. Waterwheels were and are less powerful than hydraulic turbines, but these technologies have other advantages. In some situations, waterwheels respond better than turbines to fluctuating water levels and the presence of sediment. They also bear ecological advantages: slowly turning waterwheels are less damaging to local fish stocks than high-speed turbines and are in compliance with "renaturalized" rivers. The reactivation or reconstruction of an old mill also causes significantly fewer emissions and ecological degradations than the construction of a newly designed turbine-driven power plant (Rutschmann 2013, p. 269). Given the changed decision-making conditions of the present, it may be worthwhile to reconsider these widely neglected technological paths of hydropower history.

Perceptions of energy transitions were and are depending on different points of view. Many of the early hydro-enthusiasts' visions were negotiated discursively, but did not always emerge one-to-one along the rivers and streams. The same applies to our current energy policy. At least since the Fukushima accident in 2011, reflections on both energy provision and consumption are emotionally charged and are accompanied by many hopes and fears (Blackbourn 2013, pp. 23-24). For example, the Dam Removal movements in the US and Europe, or the Save The Blue Heart of Europe campaign in several Balkan countries, express these emotional controversies in hydropower buisnesses. ${ }^{11}$ On the one hand, environmentalists set their hopes on hydropower. Present concern about energy in the face of global warming has spurred their interest. On the other hand, nature conservationists, criticize hydropower and warn against the ecological implications, particularly the transformation of riverscapes and the destruction of natural habitats. Under the banner of climate protection, a fundamental commitment to the exploitation of hydropower is coupled with diverse resentments when it comes to reactivating or implementing plants and dams on site.

Even in the current situation, it is an important task to reflect and classify the programs and ideologies that politicians, economists, and environmentalists accociate with potentials and risks of particular energy technologies and to distinguish them from their technological, social, and ecological value. As one of the first forms of "renewable" electricity, the development of hydroelectricity offers a potential historical test case for how such an energy form emerged in the past in manifold ways. In the words of economic historian Werner Abelshauser, the insights of the article suggest "caution against overly euphoric plans for the future" and-we would add--for overly dramatic and romantic obituaries too (Abelshauser 2014, p. 58). Emotional reflections, which also encompass the current energy debate, may obscure the urgent challenges of today's energy transition. These reflections

${ }^{11}$ Cf. https://damremoval.eu (30 March 2020); https://www.balkanrivers.net (30 March 2020). 
suggest a tolerant, unbiased parallel existence of different forms of energy technologies to achieve this end.

Acknowledgements Open Access funding provided by Projekt DEAL.

Open Access This article is licensed under a Creative Commons Attribution 4.0 International License, which permits use, sharing, adaptation, distribution and reproduction in any medium or format, as long as you give appropriate credit to the original author(s) and the source, provide a link to the Creative Commons licence, and indicate if changes were made. The images or other third party material in this article are included in the article's Creative Commons licence, unless indicated otherwise in a credit line to the material. If material is not included in the article's Creative Commons licence and your intended use is not permitted by statutory regulation or exceeds the permitted use, you will need to obtain permission directly from the copyright holder. To view a copy of this licence, visit http://creativecommons.org/licenses/by/4.0/.

\section{References}

Abelshauser W (2014) Der Traum von der umweltverträglichen Energie und seine schwierige Verwirklichung. VSWG 101:49-61

Bayer. Statistisches Landesamt (1927) (ed) Die bayerischen Wasserkraftanlagen. Beiträge zur Statistik Bayerns. Lindauer, Munich

Bayerl G (1987) Herrn Pfisters und anderer Leute Mühlen. Das Verhältnis von Mensch, Technik und Umwelt im Spiegel eines literarischen Topos. In: Segeberg H (ed) Technik in der Literatur. Frankfurt/M, Suhrkamp, pp 51-101

Basalla G (1988) The evolution of technology. Cambridge University Press, Cambridge

Becker F (1929) Die Elektrizität in der Mühle. Die Mühle 66:129

Behrens ECA (1789) Practische Mühlenbaukunst. Schwerin

Berg C (1995) Technologischer Fortschritt und ökonomische Regulierung. Ein evolutionärer Ansatz mit einer Fallstudie zur Entstehung und Entwicklung der Rübenzuckerindustrie in Deutschland. Peter Lang, Frankfurt

Bergthaller $\mathrm{H}$ et al (2014) From ecocriticism and environmental history to the environmental (post-)humanities: mapping common ground. Environ Hum 5:261-276

Binder B (1999) Elektrifizierung als Vision. Zur Symbolgeschichte einer Technik im Alltag. Tübinger Vereinigung für Volkskunde e.V., Tübingen

Blackbourn D (2006) The conquest of nature. Water, landscape and the making of modern Germany. WW Norton \& Company, London

Blackbourn D (2013) The culture and politics of energy in Germany. A historical perspective. RCC Perspectives 4:1-32

Buell L (2001) Writing for an endangered world. Literature, culture, and environment in the U.S. and beyond. Harvard University Press, Cambridge

Bund Heimatschutz (1904/1905) Laufenburg (= Eingabe des Bundes Heimatschutz an den Großherzog von Baden, das Großherzogliche Ministerium und die Regierung des Kantons Aargau). Mitteilungen des Bundes Heimatschutz 1:69

Camerer R (1909) Was muss der Besitzer einer Wasserkraft vom Turbinenbau wissen?, 4th edn. Hansen \& Co., Briegleb, pp 1-48

Camerer R (1914) Vorlesungen Ueber Wasserkraftmaschinen. Verlag von Wilhelm Engelmann, Leipzig/ Berlin

Cioc M (2002) The rhine. An eco-biography, 1815-2000. University of Washington Press, Seattle/London

Claas W (1929) Vergehende Welten. Die letzten Hammerwerke der bergisch-märkischen Kleineisenindustrie. Beitr Geschich Tech Ind 19:151-157

Cohn J et al (2020) Water powers: the second world war and the mobilization of hydroelectricity in Canada, the United States, and Germany. J Glob Hist 15:123-147

Dominick RH (1991) The environmental movement in Germany. Prophets \& pioneers 1871-1971. Indiana University Press, Bloomington

Edgerton D (2008) The shock of the old. Technology and global history since 1900. Profil Books, London

Engels JI (2006) Naturpolitik in der Bundesrepublik. Ideenwelt und politische Verhaltensstile in Naturschutz und Umweltbewegung 1950-1980. Schöningh, Paderborn 
Fischer K (1930) Aufgaben und Träger der Wasserkraftwirtschaft in Deutschland. In: Deutsche Wasserwirtschafts- und Wasserkraftverband e.V. (ed) Die Wasserkraftwirtschaft Deutschlands. Festschrift zur Tagung der II. Weltkraftkonferenz. Deutscher Wasserwirtschafts- und Wasserkraftverband, Berlin, pp 41-58

Fischer-Reinau L (1908) Die wirtschaftliche Ausnützung der Wasserkräfte. Bayer Ind Gewerbeblatt 40:71-111

Fricke H (1911) Wasserkraftanlagen und landschaftliche Schönheit. Heimatschutz (Mitteilungen des Deutschen Bundes Heimatschutz) 7:51-71

Fuchs CJ (1905) Die Ausnützung der Naturkräfte vom Standpunkt der Volkswirtschaft. In: Bericht über die Jahresversammlung des Bundes Heimatschutz in Goslar am 12.-14. Juni 1905. Verlag von GebauerSchwetschke, Halle/S, pp 91-95

Grantz M (1907) Kulturelle Bedeutung der Wasserwirtschaft und Entwicklung der Wasserwirtschaft in Preußen. Die Talsperre 5:157-159

Gschwandtner M (2013) Die Wasserkraftnutzung im Wandel der Zeit. Von den Wasserrädern zu den modernen Turbinen. GRIN Verlag, Salzburg

Gugerli D (1996) Redeströme. Zur Elektrifizierung der Schweiz, 1880-1914. Chronos, Zurich

Hård M, Jamison A (2005) Hubris and hybrids. A cultural history of technology and science. Routledge, New York

Hasenöhrl U (2011) Zivilgesellschaft und Protest. Eine Geschichte der Naturschutz- und Umweltbewegung in Bayern 1945-1980. Vandenhoeck \& Ruprecht, Göttingen

Hennig R (1909) Deutschlands Wasserkräfte und ihre technische Anwendung. Die Turbine 4:208-211 and 230-234.

Hiltner E (1931) Die deutschen Wasserkräfte. Wasserkr Wasserwirtsch 26:16

Hoyer F (1922) Moderne Wasserräder. Die Wasserkr 17:349-351

Hughes TP (1983) Networks of power. Electrification in western society, 1880-1930. The Johns Hopkins University Press, Baltimore

Hunter LC (1980) A history of industrial power in the United States, 1780-1930. Waterpower in the century of the steam engine. University Press of Virginia, Charlottesville

Jakobsson E (2002) Industrialization of rivers: a water system approach to hydropower development. Know Techn Pol 14:41-56

Jones CF (2016) Petromyopia: oil and the energy humanities. Humanities 5(2):36

Kammerer F (1926) Technisches und wirtschaftliches von Kleinwasserkräften. Zeitsch Bayer Revis Ver 30:104-107 and 113-115

Klimek S (2012) Waldeinsamkeit Literarische Landschaft als transistorischer Ort bei Tieck, Stifter, Storm und Raabe. Jahrbuch Raabe-Gesellsch 53:99-126

Klotzbach P (1920) Elektrizitätsanlagen und ihre architektonische Gestaltung. Zeitsch Rhein Ver Denkmalpfle Heim 13:85-91

Kneitz A (2016) Pfister's spill? Narratives of failure in and around Wilhelm Raabe's 1883 Eco-Novel. Ecozon 7(1):176-196

Koch W (1924) Kraftwerke, Gebirgsbäche und Täler. Mein Heimatland 6:128-130

Koehn T (1908) Handbuch der Ingenieurwissenschaften: Teil 3: Der Wasserbau: 13, Ausbau von Wasserkräften. Wilhelm Engelmann, Leipzig

Koehn T (1909) Über einige grosse europäische Wasserkraftanlagen und ihre wirtschaftliche Bedeutung. Die Turbine 6:110-119

Krümmel O (1903) Die geographische Verbreitung der Wind- und Wassermotoren im Deutschen Reiche. Nach der Gewerbezählung vom 14. Juni 1895 dargestellt. Petermanns Geogr Mitt 49:169-173

Lagendijk V (2016) Europe's rhine power: connections, borders, and flows. Water Hist 8:23-39

Landry M (2013) Europe's battery: the making of the alpine energy landscape, 1870-1955. Dissertation, Georgetown University

Landry M (2015) Environmental consequences of the peace: the Great War, dammed lakes, and hydraulic history in the eastern Alps. Environ Hist 20:422-448

Langdon J (2004) Mills in the medieval economy. England, 1300-1540. Oxford University Press, Oxford/ New York

Layton E (1979) Scientific technology, 1845-1900: the hydraulic turbine and the origins of American industrial research. Technol Cult 20:64-89

Layton E (1992) From rule of thumb to scientific engineering: JBF and the invention of the francis turbine. Stony Brook, New York

Lekan T (2004) Imaging the nation in nature. Landscape preservation and German identity, 1885-1945. Harvard University Press, Cambridge

Löhner (1912) Elektrizitätsversorgung und Heimatschutz. Bayer Heim 10:223-228 
Löwy M, Sayre R (2002) Romanticism against the tide of modernity. Duke University Press, Durham

Lindqvist S (1994) Changes in the technological landscape. The temporal dimension in the growth and decline of large technological system. In: Granstrand O (ed) Economics of technology. Elsevier, Amsterdam, pp 271-288

Limmer A (2019) Umwelt im Roman Ökologisches Bewusstsein und Literatur im Zeitalter der Industrialisierung. Vandenhoeck \& Ruprecht, Göttingen

Lindner W (1926) Ingenieurwerk und Naturschutz. Hugo Bermühler Verlag, Berlin

Linse U (1988) “Der Raub des Rheingoldes”. Das Wasserkraftwerk Laufenburg. In: Falter R, Linse U (ed) Von der Bittschrift zur Platzbesetzung. Konflikte um technische Großprojekte: Laufenburg, Walchensee, Wyhl, Wackersdorf. Verlag JHW Dietz Nachf., Berlin, pp 11-63

Lucas A (2004) Industrial milling in the ancient and medieval worlds. A survey of the evidence for an industrial revolution in medieval Europe. Technol Cult 46:1-30

Malone PM (2009) Waterpower in Lowell: engineering and industry in nineteenth-century america. Johns Hopkins University Press, Baltimore

Matschoß C (1925) Das Deutsche Museum, Geschichte, Aufgaben, Ziele. VDI-Verlag, Berlin

Mattern E (1908) Die Ausnutzung der Wasserkräfte. Technische und wirtschaftliche Grundlagen. Wilhelm Engelmann, Leipzig

Meyer AF (1908) Die Verwertung der Wasserkräfte. Die Talsperre 6:264-266, 274-276 and 281-283

Müller W (1899) Die Eisernen Wasserräder. Berechnung, Konstruktion und Bestimmung ihres Wirkungsgrades. 1. Teil: Die Zellenräder. Verlag von Veith \& Comp., Leipzig

Nünning A (2009) Formen und Funktionen literarischer Raumdarstellung. Grundlagen, Ansätze, narratologische Kategorien und neue Perspektiven. In: Hallet W, Neumann B (ed) Raum und Bewegung in der Literatur. Die Literaturwissenschaft und der Spatial Turn. Transcript, Bielefeld, pp 33-52

Nye D (2006) Technology matters. Questions to live with. MIT Press, Cambridge, London

Oberste Baubehörde im Bayerischen Staatsministerium des Inneren (1921) (ed) Die Wasserkraftwirtschaft in Bayern. Munich

Parrinello G (2018) Systems of power: a spatial envirotechnical approach to water power and industrialization in the po valley of Italy, ca. 1880-1970. Technol Cult 59:652-688

Popp M (2014) Wasserkraftwerke. Historisches Lexikon Bayerns. https://www.historisches-lexikonbayerns.de/Lexikon/Wasserkraftwerke. Accessed 30 March 2020

Popplow M (1998) Neu, nützlich und erfindungsreich. Die Idealisierung von Technik in der frühen Neuzeit. Waxmann, Münster

Preisendanz W (1966) Die Erzählfunktion in der Naturdarstellung bei Stifter. Wirkendes Wort 16:407-418

Pritchard S, Zeller T (2010) The nature of industrialization. In: Reuss M, Cutcliffe S (eds) The illusory boundary. Environment and technology in history. Virginia University Press, Charlottesville, pp 69-100

Quantz L (1907 [1929]) Wasserkraftmaschinen. Ein Leitfaden zur Einführung im Bau und Berechnung moderner Wasserkraft-Maschinen und -Anlagen. Springer, Heidelberg

Raabe W (1969 [1874]) Die Innerste. Eine Erzählung. In: Hoppe K, Oppermann H et al (ed) Wilhelm Raabe. Sämtliche Werke 12. Vandenhoeck \& Rupprecht, Braunschweig, pp 101-195

Raabe W (1970 [1883]) Pfisters Mühle. Ein Sommerferienheft. In: Hoppe K, Oppermann H et al (ed) Wilhelm Raabe. Sämtliche Werke 16. Vandenhoeck \& Rupprecht, Braunschweig, pp 5-178

Rehbock T (1908) Der wirtschaftliche Wert der binnenländischen Wasserkräfte. Die Weisse Kohle 1:1-3

Reichel E (1914) Über Wasserkraftmaschinen. Ein Vortrag für Bauingenieure, Oldenbourg, Munich/ Berlin

Reindl C (1923) Neue Klein-Wasserkraftanlagen. Elektrotech Zeitsch 43:1449-1451

Reynolds TS (1983) Stronger than a hundred men. A history of the vertical water wheel. Johns Hopkins University Press, Baltimore

Rohkrämer T (1999) Eine andere moderne? Zivilisationskritik, Natur und Technik in Deutschland 18801933. Schöningh, Paderborn

Rollier A (1912) Moderne Wasser-Kraftwerke. Heimatschutz 7:169-184

Rollins W (1997) A Greener vision of home. Cultural politics and environmental reform in the German heimatschutz movement, 1904-1918. University of Michigan Press, Ann Arbor

Rudorff E (1904/1905) Zur Talsperrenfrage. Mitteilungen des Bundes Heimatschutz 1:175-180

Rutschmann P (2013) Ökologische, fischfreundliche Wasserkraft an Fließgewässern. In: Grambow M (ed) Nachhaltige Wasserbewirtschaftung. Konzept und Umsetzung eines vernünftigen Umgangs mit dem Gemeingut Wasser. Vieweg+Teubner Verlag, Wiesbaden, pp 268-278

Schmoll F (2004) Erinnerungen an die Natur. Die Geschichte des Naturschutzes im Deutschen Kaiserreich, Campus, Frankfurt/M 
Schnell J (2015) Fischschutz und Fischabstieg. In: Heimerl S (ed) Wasserkraftprojekte, pp 465-472

Schoder A, Schmid M (2017) Where technology and environmentalism meet: the remaking of the Austrian Danube for hydropower. In: Petrić H, Žebec I (eds) Environmentalism in central and southeastern Europe. Historical prespectives. Lexington Books, New York, pp 3-21

Schoenichen W (1929) Der Umgang mit Mutter Grün. Ein Sünden-und Sittenbuch für jedermann. Verlag Naturkunde, Berlin

Schultze-Naumburg P (1905) Kraftanlagen in ihrer ästhetischen Bedeutung. In: Bericht über die Jahresversammlung des Bundes Heimatschutz in Goslar am 12.-14. Juni 1905. Verlag von GebauerSchwetschke, Halle a. S., pp 69-90

Schultze-Naumburg P (1906) Kraftanlagen und Talsperren. Der Kunstwart 19:130-136

Schultze-Naumburg P (1916) Kulturarbeiten. Band VIII: die Gestaltung der Landschaft durch den Menschen. II. Teil. Kunstwart-Verlage, Munich

Sellmann W (1930) Die Mühlen in Stadt und Stift Essen. Beiträge Geschichte Stadt Stift Essen 47:265-357

Sieferle R (2001 [1982]) The subterranean forest: energy systems and the industrial revolution. White Horse Press, Cambridge

Staus A (1928) Wasserradversuche. Die Mühle 65:1418-1419

Stürzenacker A (1925/1926) Die Schönheit der Ingenieurbauten, der Wasserkraftanlagen im Besonderen. Wasserkraft-Jahrbuch 2:154-172

Sturm LC (1718) Vollständige Mühlen-Baukunst. Jeremias Wolff, Augsburg

Teisch JB (2001) Great western power, "white coal", and industrial capitalism in the west. Pac Hist Rev 70:221-253

Thoma D (1928/1929) Die Bedeutung des Versuchswesens für die Ausbildung der Wasserkraftwerke. Wasserk Jahrbuch 4:247-267

Uekötter F (2015) Deutschland in Grün: Eine zwiespältige Erfolgsgeschichte. Vandenhoeck \& Ruprecht, Göttingen

Voegtle HW (1927) Die Wasserkraftnutzung und die Bedeutung der deutschen Wasserturbinenindustrie. Rees, Munich

Vogel F (1905) Die wirtschaftliche Bedeutung deutscher Gebirgswasserkräfte. Zeitschrift für Sozialwissenschaft 8:607-614

von Miller O (1908) Die Ausnutzung der deutschen Wasserkräfte. Zeitsch Agrarpol 6:401-405

Wanning B (2005) Die Fiktionalität der Natur: Studien zum Naturbegriff in Erzähltexten der Romantik und des Realismus. Weidler Buchverlag, Berlin

Weber H (2019) Zeitschichten des Technischen: zum Momentum, "Alter(n)" und Verschwinden von Technik. In: Heßler M, Weber H (eds) Provokationen der Technikgeschichte. Zum Reflexionsdruck historischer Forschung, Schöningh, Paderborn, pp 107-150

Weglöhner HW (2006) Die literatursoziologische Dimension in ETA Hoffmanns Kunstmärchen Klein Zaches genannt Zinnober. Étud German 61:593-615

White R (1995) The organic machine: the remaking of the columbia river. Hill \& Wang Pub, New York

Wildemann T (1931) Technische Kulturdenkmäler in den Rheinlanden und ihre Erhaltung. Rhein Ver Denkmalpfl Heim 25:127-157

Wilke S (2011) Pollution as poetic practice: glimpses of modernism in Wilhelm Raabe's Pfister's Mühle. Colloq German 44:195-214

Wilke S (2016) Von wilden Wassern und boshaften Naturgeistern: Gewalt und Naturbeherrschung in Wilhelm Raabes Erzählung "Die Innerste”. Colloq German 49:331-346

Winkel T (1927) Der deutsche Turbinenbau in den letzten 25 Jahren. Technisches Magazin. Ständiger Teil des Deutschen Magazins 4:45

Zeller T (2007) Driving Germany. The landscape of the German autobahn. Berghahn Books, Oxford

Zimmer F (2019) Nature, nation and the dam narratives about the harnessed waterfall in early twentiethcentury Sweden. HCM 7:171-208

Zoepfl G (1902) Nationalökonomie der technischen Betriebskraft, 1. Grundlagen. G. Fischer, Jena

Zumbrägel C (2018) "Viele wenige machen ein Viel": Eine Technik- und Umweltgeschichte der Wasserkraft (1880-1930). Schöningh, Paderborn

Zumbrägel C (2020) Urban energy consumption, mobility and environmental legacies. In: Knoll M, Mares D, Haumann S (eds) Concepts of urban-environmental history. Transcript, Bielefeld, pp 167-191

Publisher's Note Springer Nature remains neutral with regard to jurisdictional claims in published maps and institutional affiliations. 


\section{Affiliations}

\section{Agnes Limmer $^{1}$ (D) . Christian Zumbrägel ${ }^{2}$ (D)}

Christian Zumbrägel

christian.zumbraegel@tu-berlin.de

1 Institute for Advanced Study, Technical University of Munich, Lichtenbergstraße 2 a, 85748 Garching, Germany

2 Department of History of Technology, Berlin University of Technology, Straße des 17. Juni 135, 10623 Berlin, Germany 